\author{
JOSEPH R. CHAPEL ${ }^{1}$ \\ Immaculate Conception Seminary School of Theology \\ Seton Hall University \\ South Orange, NJ USA
}

\title{
The Word in the Sacrament of Confession
}

\author{
Słowo w sakramencie spowiedzi
}

In the wake of the Second Vatican Council, the Sacrament of Penance like all the Sacraments - underwent significant revision, particularly in light of a deepened sense of the significance of "word" in theology. ${ }^{2}$ A somewhat hidden contribution to this deepening is found in the work of the Austrian dialogical philosopher, Ferdinand Ebner (1882-1931). In the English speaking world, Ebner is barely known, but he is well known in Europe, and his major work, Das Wort und die geistigen Realitäten (The Word and the Spiritual Realities), ${ }^{3}$ first pub-

\footnotetext{
${ }^{1}$ Joseph R. Chapel, S.T.L., S.T.D., Theology, Accademia Alfonsiano, Lateran University, Rome (Italy), a priest of the Archdiocese of Newark, New Jersey (USA), is Associate Professor of Theology, Immaculate Conception Seminary School of Theology, Seton Hall University, South Orange, New Jersey (USA) where he has also served as Associate Dean, Associate Spiritual Director, Director of the Permanent Diaconate, Co-Director of the Institute for Christian Spirituality. He is presently on leave to serve as Spiritual Director at the Pontifical North American College, Casa Santa Maria, Rome (Italy).

${ }^{2}$ This article is adapted from a paper given by the author at the academic conference: Ferdinand Ebner: Denker des Logos und des Dia-Logos - Pneumatologie als Grammatik der Subjektivität, (Phil.-Theologischen Hochschule Brixen/Bressanone, Italy, November 19-20, 2009) and published in a somewhat different form in the conference proceedings as, J. R. Chapel, Das Wort im Sakrament der Beichte, trans. M. Flatscher, in E. Bidese, R. Hörmann, S. Zucal, eds., "Pneumatologie” als Grammatik der Subjektivität: Ferdinand Ebner (Wien/Berlin: LIT Verlag, 2012), 181-192 .

${ }^{3}$ F. Ebner, Das Wort und die geistigen Realitäten. Pnuematologische Fragmente, ed. R. Hörmann, Vienna 2009 (hereafter WgR). English translations used in this article are from H. J. Green, The Word and the Spiritual Realities: A Translation of and Critical Introduction to Ferdinand Ebner's „Das Wort und die geistigen Realitäten” and a Comparison with Martin Buber's „Ich und Du” (Ph.D. diss., Northwestern University, 1980), (hereafter Green).
} 
lished in 1921, has been translated into other languages - including Italian, ${ }^{4}$ Spanish $^{5}$ and Polish, ${ }^{6}$ - but as yet there is no published English translation. ${ }^{7}$

Nonetheless, Ebner, who has been called "the secret philosophical inspiration of modern theology," ${ }^{8}$ had a significant influence on the development of Sacramental Theology, including the Sacrament of Penance, through both the direct and indirect application of his thought.

This article will proceed in four steps: first, a brief review of Ebner's direct thought on sin, sacraments, and specifically the Sacrament of Confession; second, the influence of Ebner's thought on the Second Vatican Council's understanding of the role of the "word"; third, how this thought on the word is present in the New Rite of Penance; and finally, some implications for further study of how Ebner's thought can be applied to other language philosophies to better understand the internal dynamics of the Sacrament of Confession.

\section{WORD AND SIN}

The centerpiece of Ferdinand Ebner's thought is this: humans are given the "word"; in the word, being is founded. It is only in the word, in language, that an "I" meets a "thou," so that relationship and self-consciousness may occur. God "spoke" man and woman into being ${ }^{9}$ as the centerpiece of His creation, and chose to express Himself to us in Jesus, the "Word made flesh," 10 who dwelt among us. God thus spoke to us "in the word" and invited our response: a dialogue in which the word is the relational vehicle in, through, and because of which, each of us discovers absolute dependence on God, our Creator, the eternal Thou whose word reveals to each of us, "I am."

We can retreat from this encounter into "I-aloneness" (Icheinsamkeit), into an inauthentic world of idea or "dream of the Spirit" (Traum vom Geist). Such a "closing of oneself to the Thou" (Duverschlossenheit) is the heart of sin. While sin, itself, is not the topic of this article, it is important to have in mind that for

${ }^{4}$ La parola e le realtà spirituali. Frammenti pneumatologici, trans. P. Renner, ed. S. Zucal, Cinisello Balsamo 1998.

${ }_{5}^{5}$ La palabra y las realidades spirituales. Fragmentos pneumatológicos, trans. J. M. Garrido, Madrid 1995.

${ }^{6}$ Stowo i realności duchowe. Fragmenty pneumatologiczne, thum. K. Skorulski, Warszawa 2006.

${ }^{7}$ However, an English translation will be forthcoming, edited by Joseph R. Chapel and Harold Johnson Green (see footnote 2 above).

${ }^{8}$ J. Moltmann, Anfänge der dialektischen Theologie, 1, Mn: Kaiser, 1966, xvii, cited in $\mathrm{H}$. Waldenfels, La comprensione della rivelazione nel XX secolo, in: La rivelazione, trans. M. Ch. Laurenzi, Palermo 1992, 452: "[...] il segreto ispiratore filosofico della teologia moderna."

${ }^{9}$ See Genesis 1.

${ }^{10}$ See John 1:14. 
Ebner, authentic Confession will recognize that sin is rooted in the retreat into the world of solitary "ideas" - a rejection of authentic encounter with the thou.

For this reason Descartes' cogito must be rejected for the existence of the I is not founded or proved by solitary thinking, but only in relation with a thou. When all is said and done, while there are "many transgressions, in reality, there is only one sin, the sin: only the single sin of interior closing before God and before men.... Born into evil itself is the fact that man closes himself off and 'does not come to the light'.... All evil happens in the 'closure' of the I to the thou, in 'aloneness." "11

There is no aspect of spiritual life, not even sin, which does not have a direct and essential relationship to the word, because that life was created through the word: "All being, which has fallen from God and has become wordless, is destined to return again to the word - in man and through him." ${ }^{12}$ For the reality of sin, sacramental Confession offers the avenue for this return to the word.

\section{CHURCH \& SACRAMENT}

Any consideration of the Word in the Sacrament of Confession, in the thought of Ferdinand Ebner, must bear in mind the ambivalent relationship he had with the institutional Church throughout his adult life. It is clear in his writings that Ebner had a respect for the Church, while lamenting what he perceived as its institutional faults: its political activity, abuses, and lack of charity among the clergy. He avoided public criticism of the Church, believing it required a special vocation from God, which he did not possess. Thus Ebner did not publicly reject or rebel against his Catholic faith; while estranged from the Church, he always remained deeply devout and pursued his faith - not surprisingly - in the Word: through daily reflection on Sacred Scripture, especially the gospels, which so profoundly inform and permeate his thought. Ebner's faith is not in the written word, in the Protestant sense, but rather in the Gospel word, in St. Augustine's sense, as the word we could not have come to know if the Church had not been there to bear witness to it. ${ }^{13}$

${ }^{11}$ F. Ebner, Aphorismen, in: idem, Schriften 1, ed. F. Seyr, Munich, 997-998: "Es gibt in Wirklichkeit nur eine Sünde, die Sünde, aber viele Fehler; nur die eine Sünde der inneren Abschließung vor Gott und dem Menschen.... In diesem an und für sich liegt es, daß sich der Mensch verschließt, und 'kommt nicht an das Licht'.... Alles Böse geschieht in der 'Abschließung des Ich vor dem Du,' in der 'Icheinsamkeit.',

${ }^{12}$ H.J. Green, Fragment 17, 266; WgR, Fragment 17, 176: “Alles von Gott abgefallene und wortlos gewordene Sein soll - im Menschen und durch ihn - zum Wort wieder zurück."

${ }^{13}$ J. Puente, Ética Personalística: Una interpretación de la obra de F. Ebner (S.T.D. diss., Accademia Alfonsiana, 1976; Madrid: Imprenta Saez, 1982), 45, cf.: Die Wirklichkeit Christi, in Schriften, 1:594: "Also hätten wir uns doch auf den Standpunkt des heiligen Augustinus zu stellen, der sagte, wir könnten dem Evangelium nicht glauben, wenn nicht die Kirche uns bezeugt hätte, was überhaupt Evangelium ist." 
Even if obscured at times, the Church has continuously witnessed to this word which remains the way to reach Christ. The Church is the place of salvation to the extent that salvation and orientation for our lives is given in the word, that is, the word transmitted (überliefertes Wort) in and by the Church, a word that the Church should make fruitful, so that it remains a living (lebendig) word. ${ }^{14}$ In this sense, Ebner is sensitive to the danger that the Sacraments could be reduced to mere objects or magic, rather than formal expressions of man's I-Thou relationship with God (a concern addressed in the reformulation of the Rites after Vatican II).

In Ebner's view, when an institution, as a "sacrament," in its spiritual reality, engages the personal and dialogical dimensions of life in the faith, then it truly is an authentic Christian sign. Bearing in mind that Ebner is not a theologian but simply adopts some theological concepts for his philosophical purposes, it must be noted that within his ambivalence to the Church as an institution, he fails to grasp the Church as a true community of believers, as sacramental and relational in itself. This is a weakness in his thought and a limitation in his understanding of Sacraments.

This ambivalence also left Ebner personally at a distance from the Sacraments; as an adult, he did not entrust himself to the Sacrament of Confession, except when it was specifically expected as part of his duties as a schoolteacher in Gablitz. At times, he did express the desire to "return to the Church" and he recognized that pride was at the root of his unwillingness to confess his sins. ${ }^{15} \mathrm{It}$ was only near the end of his short life, as his friendship developed with the new parish priest - a "simple priest" as Ebner described him - that he found it possible to confess his sins in the Sacrament of Penance. ${ }^{16}$

While he did not frequent the Sacrament of Confession, neither did he reject it conceptually. Rather, he had an interest and concern for "authentic" Confession. It is precisely Ebner's insistence on the "authentic" word in dialogue that marks his contribution to the Church's own later reflection at the Second Vatican Council on God's revelation to man through His own Word made Flesh.

${ }^{14}$ J. Puente, 46, cf:: WgR, Fragment 16, 160; Die Wirklichkeit Christi, in Schriften, 1:563.

${ }^{15} \mathrm{~F}$. Ebner did reconcile with the Church at the end of his life, but had thought of it over several years. For example, in January, 1927 he wrote: "Return to the Church? How? But how? I am not capable of unburdening myself to a less than impressive priest. That is certainly pride once again...." See Tagebücher, in Schriften, 2:1017: "Zurück zur Kirche? Wie? Ja, wie? Ich vermag mich ja doch nicht dem nächstbesten Priester anzuvertrauen. Das ist freilich wieder Hochmut...." Cf.: Puente, 51.

${ }^{16}$ See A. Bertoldi, S. Zucal, Ferdinand Ebner: Vita e opera, "Communio: Rivista Internazionale de Teologia e Cultura", 175-176 (January-April, 2001), p. 15: The new "simple priest" was Heinrich Hofstätter whom Ebner found very sympathetic, and able to show him the true and communitarian face of the Church. 
Notwithstanding his own hesitations about sacramental Confession, Ebner makes the argument that in sin, being falls from God and thus loses the word, and is destined to return again to the word - in man and through him: "And through the grace of God being is lifted from its untruth and taken back completely into the word." 17 At the same time, "the knowledge of sin... must go to the word and must become word, if it is not to immortalize itself and sin in its unutterability and unstatedness." 18

The danger of sin becoming, in Ebner's words, "immortalized" in its "unstatedness," suggests the value of sacramental Confession as an authentic human experience in the word. However, in his ambivalence toward sacramental Confession, Ebner does not go that far in his own presentation, but limits himself to noting the value of bringing faults to speech in a general sense. Nonetheless, sacramental Confession does correspond to the overall sense of sacrament as word in Ebner. In his sense of the word, external signs and gestures have a place in interpersonal communication, for the word is perceptible and real when persons encounter and communicate with each other. In this way, all sacraments can be seen as word, as a medium for the encounter of man with God. ${ }^{19}$

\section{THE SACRAMENT OF CONFESSION}

Man is not isolated but has the capacity to transcend himself in dialogue with others, human and divine. Animals have no such capacity. The word is of divine origin, planted within man and at the very heart of his identity. Thus man is so constituted that he must speak if he is to live in a truly human way. Ebner's point: what is authentic and real must come into word and be spoken.

Sin, in dialogical thought, is seen not so much as a "lacking something" as a "lacking someone," specifically as the lack of the thou. When sin is understood in this way it becomes impossible to "objectify guilt," to make guilt into a "thing" which remains intimately united to the personal situation and decisions. In the same way, conversion is an attitude of the whole person in his decision to assume his responsibilities with respect to the thou. ${ }^{20}$ With sin understood as broken I-Thou relation, the repair of that relation will occur in the word.

If sin, as Ebner defines it, is "closure to the thou," then following his own argumentation, sacramental Confession is the avenue for the repair of I-Thou

${ }^{17}$ H.J. Green, Fragment 17, 266; WgR, Fragment 17, 176: "Und durch die Gnade Gottes wird es aus seiner Unwahrheit heausgehoben und ganz ins Wort zurückgenommen."

${ }^{18}$ H.J. Green, Fragment 17, 265; WgR, Fragment 17, 175: "Die Erkenntnis der Sünde... muß zum Wort hin und muß Wort werden, wenn sie nicht in ihrer Unsagbarkeit und Ungesagtheit sich und die Sünde selbst verewigen soll."

${ }^{19}$ J. Puente, 48-49.

${ }^{20}$ J. Puente, 88. 
relations. Despite his personal ambivalence toward the sacrament of Penance, Ebner recognized that, if entered into authentically, it was a sign that genuinely engaged the personal and dialogical dimensions of life in the faith, for in this sacrament,

the concrete and personal confession of our sins is demanded. This is a matter of opening oneself to the thou in the word, and in the authentic word, that is, not externally without repentance, but externally and internally in the love which is able to pull us out of our solitude. ${ }^{21}$

Ebner recognizes the impotence of any external sign that is not accompanied by an internal disposition of love, to move out of "I-aloneness" and "closure to the thou," toward the realization of the I-thou relation for, "the sacrament of Confession cannot make pardon real without the active participation on the sinner's part in the encounter with the thou." ${ }^{22}$ In the case of sin, the only way to move out of I-aloneness, which is also "closure to the thou," is to bring that sin to light in the word. The bringing to word is to confess:

The knowledge of sin must, in spite of its unutterability, come about through the word spoken to a concrete Thou (not only in a mere journal monologue, or to an ideal Thou, like the word of the poet), otherwise man perishes spiritually from it and its unutterability. ${ }^{23}$

As difficult as it is to speak our sins out loud, they must come into speech to a concrete person. It is not enough to do so in a monologue form, on paper or in one's private thoughts, or else one spiritually perishes in the pride of resistance.

As long as this knowledge renounces the word and avoids expressing itself over against a concrete Thou, a still more spiritual pride abides in it. Even in his knowledge of sin and its verbalization, the relation of man to God must find its expression in the relation of man to man - just as in love. Certainly God is in him whom I make the concrete Thou of my confession of $\sin . . .{ }^{24}$

${ }^{21}$ J. Puente, 47: “....se exige la concreta y personal confesión de nuestros pecados. Se trata de un abrirse al tú en la palabra, y en la palabra verdadera, es decir, no externamente sin arrepentimiento, sino externa e interiormente en el amor que es capaz de sacarnos de nuestra soledad." Cf.: Notizen, in Schriften, 2:494, 500; Tagebücher 1918, in Schriften, 2:858.

${ }^{22}$ J. Puente, 47, note 16: "El sacramento de la confesión no puede hacer real el perdón sin la participación activa en ese encuentro con el tú por parte del pecador." Cf.: Die Wirklichkeit Christi, in Schriften, 1:540-541; Aphorismen 1931, in Schriften, 1:998.

${ }^{23}$ H.J. Green, Fragment 17, 263; WgR, Fragment 17, 174: "Die Erkenntnis der Sünde muß, trotz ihrer Unsagbarkeit, durch das Wort hindurch, das zu einem konkreten Du gesprochen wird nicht etwa nur in einem bloßen Tagebuchmonolog oder zu einem ideelen Du wie das Wort des Dichters - sonst geht der Mensch an ihr und ihrer Unsagbarkeit geistig zugrunde."

${ }^{24}$ H.J. Green, Fragment 17, 263; WgR, Fragment 17, 174: "Solange sie auf das Wort verzichtet und es vermeidet, einem konkreten Du gegenüber sich auszusprechen, steckt in ihr noch immer geistiger Hochmut. Auch in seiner Erkenntnis der Sünde und ihrer Wortwerdung muß das Verhält- 
Because the relation to God is expressed in the relation to man, then just as with love, even sin and sorrow must be brought to God by being expressed out loud in word, to another concrete human person. To refuse this is the further sin of pride. With sorrow for sin, just as with positive expressions of love, there is a "communicative tension" toward expression.

That man speaks is a miracle, for language is placed in him by God. And the word of confession, like all word, is the "objective" vehicle of authentic relation, by which man expresses love, the "subjective" reality of authentic relation: "The word of confession originates from the love for God; the love for God grows in the word of confession. Thus we see here again how the word and love belong together in their deepest basis." 25

Any confession of faith must be also a confession of sin, for the recognition of God's love brings with it the recognition of the inadequacy of human response to that love. In this sense, a confession of faith which is not also a confession of sin,

would be an empty and meaningless word, a misuse and a sacrilege of the word. In the confession of sin man believes in the word, which is from God and descended from heaven in order to dwell among us; he believes in redemption through the word. ${ }^{26}$

The I-Thou relationship with God brings a deepening of faith with an increased awareness of God's forgiving love revealed in the word; in this context the awareness of sin becomes more obvious, and man's sorrow can be a striking witness of love. But even in the face of God's love and grace, there can be a resistance to openness:

Sin is revealed in the word.... And if in this life man in the taciturnity [closure to the Thou] of his heart hinders the word "in time," then on the day of judgment it is hindered for all eternity. ${ }^{27}$

Without explicit reference, Ebner points to the effectiveness of the words of absolution in sacramental Confession. It is pride to refuse to bring sin to the word,

nis des Menschen zu Gott - wie in der Liebe - in Verhältnis zum Menschen seinen Ausdruck finden. Gewiß ist in dem, den ich zum konkreten Du meines Sündenbekenntnisses mache, Gott...."

${ }^{25}$ H.J. Green, Fragment 17, 263; WgR, Fragment 17, 174: "Das Wort des Bekenntnisses entspringt aus der Liebe zu Gott, die Liebe zu Gott wächst im Wort des Bekenntnisses. So sehen wir auch hier wieder, wie das Wort und die Liebe im tiefsten Grunde zusammengehören."

${ }^{26}$ H.J. Green, Fragment 17, 263; WgR, Fragment 17, 174: "[Eines] wäre ein leeres, nichtssagendes Wort, ein Mißbrauch des Wortes und Frevel an ihm. Im Sü?ndenbekenntnis glaubt der Mensch an das Wort, das von Gott ist und das vom Himmel herabstieg, um unter uns zu wohnen, glaubt er an die Erlösung durch das Wort."

${ }^{27}$ H. J. Green, Fragment 17, 264; WgR, Fragment 17, 174: "Die Sünde wird im Worte offenbar - und wenn es der Mensch in diesem Leben in der Verschlossenheit seines Gemüts «in der Zeit» verhindert, dann am Tage des Gerichts für alle Ewigkeit....” 
but such a choice has potential consequence for life beyond "time." The key again is what Ebner has called, the one sin: "thou-taciturnity" or closing of oneself to the thou, a prideful decision to remain in "I-aloneness," with the illusion of self-sufficiency.

\section{VATICAN II}

It is clear that Ferdinand Ebner had some concrete views about the Sacrament of Confession. However, his influence on the New Rite of Penance is only indirect - it comes as the "application" of a more direct influence on the Second Vatican Council, most especially in the "Dogmatic Constitution on Divine Revelation," Dei Verbum. Therefore, this direct influence will be considered first, in order to understand its indirect influence on the New Rite of Penance.

The centrality of the word is notable in various places throughout the documents of Vatican II. From Sacrosanctam Concilium, the first document approved at the Council, which opens acknowledging God's call to humanity through the prophets and later through the Word, ${ }^{28}$ to Dei Verbum, approved at the end of the last Council session, which likewise opens with God's call to humanity, ${ }^{29}$ one of the themes that emerges throughout is the dialogical nature of all human encounter with God. For this reason, it might be said that theological renewal in the af-

28 "Constitution on the Sacred Liturgy," Sacrosanctum Concilium 5, in ed. A. Flannery OP, Vatican Council II: The Conciliar and Post Conciliar Documents (New York: Costello Publishing Co., 1987, rev. 1988): "God who... 'in many times and various ways spoke of old to the fathers through the prophets' (Heb. 1:1), when the fullness of time had come sent His Son, the Word made flesh, anointed by the Holy Spirit..., to be a 'bodily and spiritual medicine,' the Mediator between God and man. For His humanity, united with the person of the Word, was the instrument of our salvation."

29 "Dogmatic Constitution on Divine Revelation," Dei Verbum 2, in Flannery, Vatican Council II: "In His goodness and wisdom God chose to reveal Himself and to make known to us the hidden purpose of His will (Eph. 1:9) by which through Christ, the Word made flesh, man might in the Holy Spirit have access to the Father and come to share in the divine nature (Eph. 2:18; 2 Peter 1:4). Through this revelation, therefore, the invisible God (Col. 1;15, 1 Tim. 1:17) out of the abundance of His love speaks to men as friends (Ex. 33:11; John 15:14-15) and lives among them (Bar. 3:38), so that He may invite and take them into fellowship with Himself. This plan of revelation is realized by deeds and words having an inner unity: the deeds wrought by God in the history of salvation manifest and confirm the teaching and realities signified by the words, while the words proclaim the deeds and clarify the mystery contained in them. By this revelation then, the deepest truth about God and the salvation of man shines out for our sake in Christ, who is both the mediator and the fullness of all revelation...." $D V$ 4: "Then, after speaking in many and varied ways through the prophets, 'now at last in these days God has spoken to us in His Son' (Heb. 1:1-2). For He sent His Son, the eternal Word, who enlightens all men, so that He might dwell among men and tell them of the innermost being of God (John 1:1-18). Jesus Christ, therefore, the Word made flesh, was sent as 'a man to men.' He 'speaks the words of God' (John 3;34), and completes the work of salvation which His Father gave Him to do" (John 5:36; 17:4). 
termath of Vatican II has occurred within the understanding that all relations between God and humanity are dialogical.

This is most notable in Dei Verbum, which, as Joseph Ratzinger points out, reflects a very different understanding of God's revelation, considerably influenced in this century by the dialogical personalism of Ferdinand Ebner, Martin Buber and others (largely filtered through Karl Barth's influence). ${ }^{30}$

If Dei Verbum is contrasted with Dei Filius, Vatican I's reflection on revelation, a few significant elements emerge. ${ }^{31}$ Vatican I starts from the natural knowledge of God and considers "supernatural" revelation only in relation to this idea, in order to proceed directly to its transmission in scripture and tradition. However, in Dei Verbum 2,

the question of the natural knowledge of God is put at the end and God's revealing activity described within a comprehensive survey of salvation history.... We first have a reference to God Himself, "in his wisdom and goodness," thus giving a far greater emphasis to the personal and theocentric starting point when compared to Vatican I....32

Secondly, where Vatican I portrays revelation legalistically as the issuing of divine decrees, Vatican II speaks of God's will as sacramentum, "a sacramental view, which sees law and grace, word and deed, message and sign, the person and his utterance within the one comprehensive unity of the mystery." ${ }^{33}$ The mystery is the mystery of God which is, "ultimately nothing other than Christ himself - it is the person. From this there follows an understanding of revelation that is seen basically as dialogue, as is indicated in the words alloquitur and conversatur." 34

In this dialogical context, in the reading of Scripture, "a dialogue takes place between God and man." ${ }^{35}$ The reading of Scripture reaches its highest point when the Church, "listens to the word of God in common in the sacred liturgy and within this framework itself experiences the active presence of the Logos, the Word in the words." ${ }^{36}$

${ }^{30}$ J. Ratzinger, "Dogmatic Constitution on Divine Revelation," in ed. H. Vorgrimler, and others, Commentary on the Documents of Vatican II, vol. 3 (New York: Herder, 1969), 170.

${ }^{31}$ See DV 2 and Vatican I, Dei Filius in DS3004f in H. Denzinger and P. Hunerman, Enchiridion Symbolorum: A Compendium of Creeds, Definitions, and Declarations of the Catholic Church (Latin Edition) (San Francisco: Ignatius, 2012).

32 J. Ratzinger, "Dogmatic Constitution," 170-171.

${ }^{33}$ J. Ratzinger, "Dogmatic Constitution," 171.

${ }^{34}$ J. Ratzinger, "Dogmatic Constitution," 171; alloquitur and conversatur are variously translated as "speak," "address," "converse," etc.

${ }^{35}$ DV 25.

${ }^{36}$ J. Ratzinger, "Dogmatic Constitution," 271; see DV 25. 
God's dialogue is always actual; as I-Thou dialogue it always takes place in the present tense, which means that the reference in Dei Verbum 2 to the address,

"no longer do I call you servants... but... friends," is given here and now with the intention of forcing us to reply. Thus we can see how the idea of revelation also outlines a conception of man: man as the creature of dialogue who, in listening to the word of God, becomes contemporaneous with the presentness of God and in the fellowship of the word receives the reality which is indivisibly one with this word: fellowship with God himself. ${ }^{37}$

Likewise, according to Ratzinger, there is a new relation between the word and the event which attempts to overcome a neo-scholastic view of revelation as a collection of supernatural teachings to be accepted in faith. Rather, Vatican II wanted to portray revelation as: "a totality, in which word and event make up one whole, a true dialogue which touches man in his totality, not only challenging his reason, but, as dialogue, addressing him as a partner, indeed, giving him his true nature for the first time." 38

The quotation from Hebrews 1, which was used at the beginning of Dei Filius, is used again in Dei Verbum 4, to show not only the continuity of divine history with men, but also to reveal what is truly new in the New Testament:

instead of words, we have the Word. Christ no longer speaks merely of God, but he is himself the speech of God; this man is himself and as an entity the Word of God that has made himself one of us.... In him God has, as it were, said himself. ${ }^{39}$

Therefore, the nature of God's revelation cannot be captured strictly by intellectualism for it does not talk about something that is somehow external to the person. Rather, revelation is concerned with, "the relation of the human «I» to the divine «thou,» so that the purpose of this dialogue is ultimately not information, but unity and transformation." 40

Where Vatican I tried to define the relation between natural and supernatural revelation, Dei Verbum approaches the divine-human relationship in more philosophical terms: "The symbol used is the Word since a word is the privileged mode for communicating thought, emotion, or purpose. This Word is not one of «laws and decrees» as in Vatican I, but the secret purpose or mystery (sacramentum) of God's will." ${ }^{41}$ In this Word, what is transcendent has drawn near to us.

${ }^{37}$ J. Ratzinger, "Dogmatic Constitution,” 171, citing John 15:15.

${ }^{38}$ J. Ratzinger, "Dogmatic Constitution," 172.

${ }^{39}$ J. Ratzinger, "Dogmatic Constitution," 175, citing R. Latourelle, Theology of Revelation (Théologie de la Révélatíon) (New York: Alba House, 1966) and K. Rahner, "The Development of Dogma," Theological Investigations 1 (London: Darton, Longman \& Todd, 1961), 39-78.

${ }^{40}$ J. Ratzinger, "Dogmatic Constitution," 175.

${ }^{41}$ P. Gibbs, The Word in the Third World (Rome: Gregorian University Press, 1996), 27; see also K. McNamara, "Divine Revelation,” Irish Theological Quarterly 34 (1967), 3-7. 
Although Christ was the end of God's speaking, "this end is nothing but man's being constantly addressed by God, it is the constant relating of man to the one man who is the Word of God himself." ${ }^{42}$ Therefore, what stands out most notably in Vatican II's understanding of revelation is that it is God who continually takes the initiative to make Himself known to us:

God broke the silence; God came out of His mystery; He addressed Himself to man and unveiled for him the secrets of His personal life; to man He communicated His unheard-of plan for a covenant with man, offering him a share in life. God, the living God, has spoken to humanity. ${ }^{43}$

In this understanding of revelation as dialogical, the considerable, if sometimes indirect, influence of Ferdinand Ebner is apparent.

\section{THE NEW RITE OF PENANCE}

Having now seen the significant prominence of the word in the Second Vatican Council, the centrality of the word is presupposed in the new Rite of Penance. While not mentioned often, it is a "given" and is something new in the revised Rite of Penance.

The Second Vatican Council's, "Constitution on the Sacred Liturgy," Sacrosanctum Concilium, decreed that: "The rite and formulae of Penance are to be revised so that they more clearly express both the nature and effect of the sacrament." 44 In the new Rite of Penance itself, there are only seven direct references to Vatican II documents, none of which directly address actual verbal confession of sins. ${ }^{45}$ Nonetheless, the New Rite does reflect a significant underlying influence of the re-emphasis on the Word, characteristic of Vatican II.

The new Rite of Penance makes sacramental confession more explicitly an encounter with Jesus, the Word made flesh, by way of an encounter in the word - the word of God in Sacred Scripture. The introduction to the rite begins with a scriptural reflection on the mystery of reconciliation in salvation history which specifically states that one of the ways of repentance among the people of God is for the faithful to "confess that they are sinners and ask pardon of God and of their brothers and sisters." And one of the ways this takes place is "in the proclamation of the word of God." 46

\footnotetext{
${ }^{42}$ J. Ratzinger, "Dogmatic Constitution," 175.

${ }^{43}$ R. Latourelle, Theology of Revelation, 13.

${ }^{44}$ Rite of Penance (Ordo Paenitentiae, 1973), in The Rites of the Catholic Church, vol. 1, 517-629, at 523, citing Sacrosanctum Concilium, 72.

${ }^{45}$ See A. Biazzi, "Le citazioni nei Praenotanda dell'Ordo Paenitentiae: Natura e significato," Ephemerides Liturgicae 106 (1992): 81-116, particularly section III.1.B, "Concilio Vaticano II,"

${ }^{46}$ Rite of Penance, 4.
} 106-107. 
In the celebration of the rite itself, the actual confession of sins is situated in the word: After the priest welcomes the penitent, but prior to the confession of sins, "the occasion may be taken for the priest, or even the penitent, to read a text of holy Scripture... for through the word of God Christians receive light to recognize their sins and are called to conversion and to confidence in God's mercy." ${ }^{47}$ Rather than facing a strictly juridical experience, the penitent is invited in this way to an experience of Christ personally calling him to conversion, speaking to his heart in the word.

In the "Rite for Reconciliation of Several Penitents," the emphasis on word, in an ecclesial context, is more pronounced still:

When a number of penitents assemble at the same time to receive sacramental reconciliation, it is fitting that they be prepared for the sacrament by a celebration of the word of God.... The faithful listen together to the word of God, which as it proclaims his mercy invites them to conversion; at the same time they examine the conformity of their lives with that word of God and help each other through common prayer. ${ }^{48}$

It becomes clear that the context for confession of sins is dialogue with the word of God: the awareness of God's mercy as revealed in the word helps the penitent to examine how his life responds to that word. Thus, to give ample time and weight to that word there should be "a period of silence... so that the word of God may be more deeply understood and heartfelt assent may be given to it." ${ }^{\prime 99}$ Further, the homily should be based on the scripture readings and, in the context of the word, speak of how sin works against God, self, neighbor and community. ${ }^{50}$

Finally, even the examination of conscience is situated in reference to the word, for it follows the reading of the word and the homiletic comment on that word. ${ }^{51}$ Thus every aspect of Confession is to grow out of the specific encounter with Jesus in the word. Having heard the word, reflected on it, and examined his conscience in light of the word, the penitent is now ready to confess his sins, to bring them to speech in the miracle of the word.

It is true that the new Rite of Penance has little to say "quantitatively" about the direct dialogical nature of the word in this Sacrament. However, this is not a fault or a lack, but rather it must be recalled that the new Rite is already taking as a "given," what was already "absorbed" into the Church's thinking as a result of a more penetrating understanding of the word, as dialogical, following the Second Vatican Council.

\footnotetext{
${ }^{47}$ Rite of Penance, 17.

${ }^{48}$ Rite of Penance, 22.

${ }^{49}$ Rite of Penance, 24.

${ }^{50}$ Rite of Penance, 25.

${ }^{51}$ Rite of Penance, 26.
} 


\section{IMPLICATIONS}

As at least one theologian has noted, it is surprising, that given the symbolic aspect of Word as the mode of God's self-communication, "there are very few theologians who elaborate these notions of word... by making a comparison to the philosophy of language." ${ }^{52}$ While this must wait for further research, a further elaboration of Ebner's influence on the Sacrament of Confession comes through another indirect path: the use of his thought as a prism through which to apply other language philosophies to the Sacrament of Confession.

In Ferdinand Ebner's thought on the foundational nature of the word for human identity, he gives us the "why" of language, but he does not offer a structured program for the "how" of language. At the same time, much of the Philosophy of Language gives us the "how" of the operation of language, but little of the "why."

Therefore, Ebner's work offers us a prism through which the thought of various philosophers of language may be cautiously applied to the internal operation of the Sacraments, specifically the Sacrament of Confession. Because the Sacraments are ordered to the way in which the human person is constituted by the Creator, such a consideration of language philosophies through the prism of Ebner's thought will allow us to benefit from a variety of sources, such as: the contributions of Ludwig Wittgenstein's thought on language games and private language; Martin Heidegger's thought on naming and the centrality of speech for "being"; J. L. Austin's theories of "performative language"; the semiotic theories of Ferdinand de Saussure and Charles Sanders Peirce about the symbolic content of speech; the Symbolic Sacramentology of Louis-Marie Chauvet which recovers the "bodiliness" of the Sacraments; and the work of Walter Ong on the primacy of the word.

All of these, examined through the prism of Ebner's thought will allow the believer to better understand the meaning of the Sacrament of Confession and approach it with more confidence. ${ }^{53}$ This will form the basis of a subsequent study.

${ }^{52}$ R. Latourelle, Theology of Revelation, 208.

${ }^{53}$ For more on the topics found in this paper see, J. R. Chapel, "Why Confess Our Sins Out Loud?: Some Possibilities Based on the Thought of Ferdinand Ebner and Louis-Marie Chauvet," Irish Theological Quarterly 66 (2001): 141-156; "Philosophy in the Ongoing Renewal of Moral Theology: Dialogical Personalism Revisited," Studia Moralia 40 (2002): 205-236; "Philosophy as Preparation for Sacramental Theology and Moral Life, Seminary Journal 11, no. 1 (Spring, 2005): 27-35. 


\begin{abstract}
SUMMARY
The work of the Austrian dialogical thinker, Ferdinand Ebner, had both a direct and an indirect influence on the development of the Sacrament of Penance after Vatican Council II. Ebner's notion that humans are given the "word" by God, who is the "Eternal Thou," informed Vatican II's deepening theology of the word. Sin is understood as a rejection of dialogue, a closing of oneself to the Thou, for which authentic sacramental Confession offers the remedy, in and through the miracle of God's gift of speaking to humans. Ebner's influence on Vatican II is direct, especially in the elaboration of the "Dogmatic Constitution on Divine Revelation," Dei Verbum, while his influence on the New Rite of Penance is indirect - reflected in a deeper theology of the word that had already been "absorbed" by the Council. There are implications for further study of Ebner's thought as a prism through which to apply other language philosophies to better understand the Sacrament of Confession.
\end{abstract}

\title{
Keywords
}

Ebner, I-thou, dialogue, dialogical philosophy, sacrament, reconciliation, Penance, Confession, auricular confession, Revelation, Dei Verbum

\section{STRESZCZENIE}

Dzieło austriackiego filozofa dialogu Ferdynanda Ebnera miało zarówno bezpośredni, jak i pośredni wpływ na rozwój sakramentu pokuty po II Soborze Watykańskim. Jego pogląd, że ludzie otrzymali „słowo” od Boga, który jest „Wiecznym Ty”, wpłynęło na pogłębienie soborowej teologii słowa. Grzech rozumiany jest jako odrzucenie dialogu, zamknięcie się na Ty, na co lekarstwo przynosi autentyczna sakramentalna spowiedź w i poprzez cud Boskiego daru słowa skierowanego do ludzi. Wpływ Ebnera na Sobór jest tu bezpośredni, zwłaszcza na opracowanie Konstytucji dogmatycznej o Objawieniu Bożym Dei Verbum, natomiast wpłynął on pośrednio na nowy Obrzęd Sakramentu Pokuty, co widać w pogłębionej teologii słowa, która już wcześniej została „wchłonięta” przez Sobór. Warto podjąć dalsze studium nad myślą Ebnera jako pryzmatu, przez który można zastosować inne filozofie języka dla lepszego zrozumienia sakramentu spowiedzi.

\section{Słowa kluczowe}

Ebner, ja-ty, dialog, filozofia dialogu, sakrament, pojednanie, pokuta, spowiedź, spowiedź uszna, objawienie, Dei Verbum

Tłumaczenie na j. polski: Sławomir Nowosad

\section{BIBLIOGRAPHY}

Bertoldi A., Zucal S., Ferdinand Ebner: Vita e opera, „Communio: Rivista Internazionale di Teologia e Cultura” 175-176. January-April, 2001.

Chapel J.R., "Das Wort im Sakrament der Beichte." Trans. Markus Flatscher. In "Pneumatologie" als Grammatik der Subjektivität: Ferdinand Ebner, eds. E. Bidese, R. Hörmann, S. Zucal, Wien - Berlin: LIT Verlag, 2012, p. 181-192. ISBN 3643503911, 9783643503916 
Chapel J.R., Philosophy as Preparation for Sacramental Theology and Moral Life, ,Seminary Journal” 11, no. 1. Spring, 2005, p. 27-35.

Chapel J.R., Philosophy in the Ongoing Renewal of Moral Theology: Dialogical Personalism Revisited, „Studia Moralia” 40 (2002), p. 205-236.

Chapel J.R., Why Confess Our Sins Out Loud?: Some Possibilities Based on the Thought of Ferdinand Ebner and Louis-Marie Chauvet, „Irish Theological Quarterly” 66 (2001), p. 141-156.

Ebner F., Das Wort und die geistigen Realitäten. Pnuematologische Fragmente, ed. Richard Hörmann, Vienna: LIT Verlag, 2009. ISBN 9783700007388,9783825887223

Ebner F., La palabra y las realidades spirituales. Fragmentos pneumatológicos, trans. J.M. Garrido, Madrid: Caparrós Editores, 1995. ISBN 8487943357

Ebner F., La parola e le realtà spirituali. Frammenti pneumatologici, trans. P. Renner, ed. S. Zucal, Cinisello Balsamo (Milan): Edizioni San Paolo, 1998. ISBN 8821538206, 9788821538209

Ebner F., Schriften 1, 2, 3, ed. F. Seyr, Munich: Lösel Verlag, 1963-1965. ISBN none

Ebner F., Stowo i realności duchowe: fragmenty pneumatologiczne, trans. K. Skorulski, Warsaw: Wydawnictwo IFiS PAN, 2006. ISBN 8373881131, 9788373881136

Gibbs Ph., The Word in the Third World, Rome: Gregorian University Press, 1996. ISBN $8876526978,978-8876526978$

Green H.J., „The Word and the Spiritual Realities: A Translation of and Critical Introduction to Ferdinand Ebner's „Das Wort und die geistigen Realitäten” and a Comparison with Martin Buber's” „Ich und Du”, Unpublished Ph.D. diss., Northwestern University, 1980.

Latourelle R., Theology of Revelation (Théologie de la Révélatíon), New York: Alba House, 1966. ISBN 1608991423, 978-1608991426

Moltmann J., Anfänge der dialektischen Theologie, 1, Mn: Kaiser, 1966. ISBN none

Puente Lopez J., Ética Personalística: Una interpretación de la obra de F. Ebner, Madrid: Imprenta Saez, 1982. ISBN none

Puente Lopez J., Ferdinand Ebner: Testigo de la la luz y profeta, Madrid: Revista Estudios, 2006. ISBN 8495494221, 9788495494221

Rahner K., The Development of Dogma, in: Theological Investigations 1. London: Darton, Longman \& Todd, 1961, p. 39-78. ISBN 0824503775, 978-0824503772

Ratzinger J., Dogmatic Constitution on Divine Revelation, in Commentary on the Documents of Vatican II, vol. 3., ed. H. Vorgrimler, and others, New York: Herder, 1969. ISBN 0223292206, 978-0223292208

Vatican Council II, Constitution on the Sacred Liturgy Sacrosanctum Concilium, in Vatican Council II: The Conciliar and Post Conciliar Documents, ed. A. Flannery OP, New York: Costello Publishing Co., 1987, rev. 1988. ISBN 0918344395, 978-0918344397 
Vatican Council II, Dogmatic Constitution on Divine Revelation Dei Verbum, in Vatican Council II: The Conciliar and Post Conciliar Documents, ed. A. Flannery OP, New York: Costello Publishing Co., 1987, rev. 1988. ISBN 0918344395, 978-0918344397

Vatican Council I, Dei Filius, in H. Denzinger, P. Hunerman, Enchiridion Symbolorum: A Compendium of Creeds, Definitions, and Declarations of the Catholic Church (Latin Edition), San Francisco: Ignatius, 2012: DS3004ff. ISBN 0898707463, 9780898707465

Waldenfels, H., „La comprensione della rivelazione nel XX secolo.” In La rivelazione. Trans. Maria Christina Laurenzi. Palermo: Edizioni Augustinus, 1992). ISBN none

McNamara K., Divine Revelation, „Irish Theological Quarterly” 34(1967), p. 3-7.

Rite of Penance (Ordo Paenitentiae, 1973), in The Rites of the Catholic Church, vol. 1. New York: Pueblo Publishing Co., 1976, p. 517-629. ISBN 0814660150, 978-0814660157

Biazzi A., Le citazioni nei Praenotanda dell'Ordo Paenitentiae: Natura e significato, „Ephemerides Liturgicae” 106(1992), p. 81-116. Especially section III.1.B, “Concilio Vaticano II," p. 106-107. 